УДК 331.108 .43

https://doi.org/10.35546/kntu2078-4481.2020.1.2.8

М.О. ОВЧИНИКОВА

Херсонський національний технічний університет ORCID: 0000-0002-7422-7617

Є.С. ДЕЛІСВА

Херсонський національний технічний університет

\title{
ЗАБЕЗПЕЧЕННЯ ЕФЕКТИВНОГО ПРОВЕДЕННЯ ОЦІНКИ ПЕРСОНАЛУ
}

Очінка персоналу є багатоичільовим прочесом. Вона необхідна для оптимізації таких напрямків діяльності організачії, як атестачія, підбір і розстановка кадрів, скорочення персоналу. За допомогою оцінки можна формувати кадровий резерв і покращувати комунікаційні зв'язки, відстежувати процес особистісного і професійного зростання, планувати навчання. Стаття присвячена розгляду прочесу ефективної оцінки персоналу на підприємстві.

Зосереджено увагу на питанні можливих помилок та неточностей в організаиї процесу оцінки персоналу, такі, як: необтрунтованість проведення (за иілями і термінами); зайва складність процедур $і$ методик для оцінювання; використання неперевіреного або вже неактуального інструментарію, головне завдання якого - добитися негативного результату; надмірність застосовуваних методів; нехтування правилами; фокусування не на компетенціях і результати, а на особливостях і поведінкових властивості особистості окремих співробітників; непідготовленість керівників, в периу чергу у виконанні інформаційних функиій $і$ об'єктивному застосуванні оціночних інструментів; невикористання результатів проведеної оцінки в ичілях розвитку співробітників.

В контексті досліджуваної проблеми розкрито сутність сучасних методів очінки персоналу в організації, щ⿻о обираються виходячи з поставлених изілей $і$ завдань та недоліки процесу оцінювання.

Наголошено на потребі всебічної, комплексної оцінки персоналу відповідно до умов сьогодення, а також використання новітніх наукових підходів для забезпечення ефективності оичінки персоналу на підприємстві.

Ключові слова: очінка персоналу, сучасні методи оцінки персоналу, професійний потенціал робітника, ефективність оцінки персоналу підприємства.

М.А. ОВЧИНИКОВА

Херсонский национальный технический университет ORCID: 0000-0002-7422-7617

Е.С. ДЕЛИЕВА

Херсонский национальный технический университет

\section{ОБЕСПЕЧЕНИЕ ЭФФЕКТИВНОГО ПРОВЕДЕНИЯ ОЦЕНКИ ПЕРСОНАЛА}

Оиенка персонала является многоцелевым прочессом. Она необходима для оптимизации следующих направлений деятельности организаџии, как аттестащия, подбор и расстановка кадров, сокращение персонала. С помощью оченки можно формировать кадровый резерв и улучшать коммуникационные связи, отслеживать процесс личностного и профессионального роста, планировать обучение. Статья посвящена рассмотрению процесса эффективной оценки персонала на предприятии.

Сосредоточено внимание на вопросе возможных ошибок и неточностей в организации процесса оценки персонала, такие, как: необоснованность проведения (по целям и срокам); излишняя сложность процедур и методик для оценивания; использование непроверенного или уже неактуального инструментария, главная задача которого - добиться отрицательного результата; избыточность применяемых методов; пренебрежение; фокусировка не на компетенциях и результатах, а на особенностях и поведенческих свойствах личности отдельных сотрудников; неподготовленность руководителей, в первую очередь в выполнении информационных функций и объективном применении оценочных инструментов; использование результатов проведенной оценки в целях развития сотрудников.

В контексте исследуемой проблемы раскрыты сущность современных методов оценки персонала в организации, которые выбираются исходя из поставленных иелей и задач и недостатки прочесса оценивания.

Подчеркнута необходимость всесторонней, комплексной оценки персонала в соответствии с условиями настоящего, а также использование новейших научных подходов для обеспечения эффективности оценки персонала на предприятии. 
Ключевые слова: оценка персонала, современные методы оченки персонала, профессиональный потенциил работника, эффективность оценки персонала предприятия.

M.O. OVCHYNNYKOVA

Kherson National Technical University ORCID: 0000-0002-7422-7617

E.S. DELIEVA

Kherson National Technical University

\section{ENSURING OF EFFECTIVE EVALUATION OF STAFF}

Personnel evaluation is a multi-purpose process. It is necessary to optimize the following aspects of the organization, such as certification, selection and placement, staff reduction. Through evaluation it is possible to form a personnel reserve and to improve communication, monitor personal and professional growth, to plan training. The article is devoted to the process of effective evaluation of personnel.

It focuses on the question of possible errors and inaccuracies in the organization of the evaluation process, such as: lack of substantiation of the event (for objectives and time frames); the excessive complexity of the procedures and techniques for assessment; the use of untested or irrelevant tools, whose main task is to achieve a negative result; the redundancy of the technique used; the neglect; the focus on competencies and outcomes, and the characteristics and behavioral properties of the personality of individual employees; the lack of preparedness of the leaders, primarily in the implementation of information functions and objective application of valuation tools; the use of evaluation for development workers.

In the context of the problem under study considers the essence of modern methods of personnel assessment in the organization, selected on the basis of the goals and objectives and disadvantages of the evaluation process.

Stressed the need for a comprehensive, integrated assessment of staff in accordance with the terms and conditions, as well as using the latest scientific approaches to ensure the effectiveness of personnel assessment in the company.

Keywords: personnel evaluation, modern methods of personnel evaluation, and professional potential of the employee, the evaluation of personnel.

\section{Постановка проблеми}

Розробка ефективних методів мотивації та оцінки персоналу є однією з найважливіших задач сучасного менеджменту. Різноманіття теоретичних підходів створює непросту ситуацію для служб управління персоналом, адже від правильного вибору методу оцінки залежить не тільки успішність системи стимулювання, а й ступінь задоволеності працівників, що в комплексі має позитивний вплив на економічні показники підприємства.

За даними дослідницьких центрів, правильна система оцінка кандидатів на вході в компанію економить до 200\% витрат, пов'язаних з підбором і адаптацією персоналу. Зниження витрат відбувається за рахунок зосередження кадрового забезпечення на зменшення плинності кадрів та скорочення витрат часу на заповнення однієї вакансії. Впровадження якісної системи оцінювання здатне знизити плинність кадрів до 50\% в залежності від середнього обігу персоналу, підвищити продуктивність праці в період адаптації нового працівника на 20-30\% та скоротити витрати, пов'язані з його виробничою діяльністю до 60\%. При цьому термін закриття вакансії може скоротитися вдвічі, але в залежності від важкості ситуації та вибору способу оцінювання. Подібні зміни здатні позитивно вплинути на прибуток підприємства та уберегти від зайвих витрат.

Аналіз останніх досліджень і публікацій

Теоретичні та методологічні аспекти оцінки персоналу підприємства висвітлила низка зарубіжних та вітчизняних учених, зокрема: М.Х. Мескон, Г.Д. МакГрегор, Мінцберг та П. Друкер. Л.В. Балабанова, О.А. Грішнова, В.М. Данюк, О.В. Крушельницька, А.М. Колот, А.Я. Кибанов, І.Л. Петрова, В.М. Петюх та ін. Результатом їніх досліджень було розроблення різноманітних підходів, процедур і методів організації та проведення оцінки персоналу. Актуальними залишається пошук сучасних підходів до комплексної оцінки персоналу з врахуванням неточностей та помилок.

\section{Формулювання мети дослідження}

Метою статті є визначення факторів ефективного проведення оцінки персоналу підприємства та розкриття питань щодо можливих помилок та неточностей в організації процесу оцінки персоналу.

\section{Викладення основного матеріалу дослідження}

Методи оцінки персоналу в організації обирають виходячи 3 поставлених цілей і завдань. Виділяють три основні цілі оцінки персоналу [1]:

1. Адміністративна. Сприяє прийняттю управлінських рішень. 
2. Інформаційна. Допомагає персоналу краще розібратися у своїй діяльності, а управлінцям вказує на вузькі місця підлеглих.

3. Мотивуюча. Дає співробітникам можливість проявити свої найкращі якості та отримати за це винагороду і визнання.

Оцінка персоналу в організації вирішує низку важливих завдань. ІІЇ систематичне проведення дає змогу менеджерам створити дієву управлінську політику та налагодити зворотній зв'язок між керівником та підлеглим на всіх рівнях управління. В цілому основне завдання оцінки персоналу полягає в консолідації всіх елементів системи управління з метою підвищення рівня якості робити організації. 3 цією загальною метою перетинаються такі основні напрямки діяльності в сфері управління персоналом, як створення кадрового резерву, сприяння розподілу співробітників за компетенціями, виявлення потреби в навчанні та розвитку персоналу та інші.

Згідно з даними сайду з пошуку роботи Head Hunter, 72\% компаній застосовують методи оцінки персоналу для найму працівників, $62 \%$ - для просування своїх співробітників та $40 \%$ - для виявлення перспективних працівників [5].

Слід зазначити, що методи крім цілей і завдань відрізняються способом оцінки. За спрямованістю основні методики поділяють на: якісні, кількісні, комплексні та комбіновані [4]. Всі вони вирізняються критеріями оцінки i набором інструментів, який застосовується HR-відділом або керівництвом.

Якісні або описові методи оцінки. Їх відмінною рисою $є$ характеристика працівників без застосування кількісних показників на основі аналізу їх здібностей і індивідуальних поведінкових особливостей. Ці методи використовують для формування проміжної оцінки роботи персоналу в колективі, але найчастіше при первинному відборі на роботу. До якісних методів оцінки персоналу належать:

1. Матричний метод. Передбачає порівняння характеристик співробітника 3 еталонними. Цей метод $€$ найбільш простим в застосуванні, що робить його найпоширенішим.

2. Метод довільних характеристик. Передбачає визначення найкращих досягнень співробітника i його сильних сторін. Дані зіставляються з найбільш грубими помилками в роботі, 3 чого робляться висновки про успішність і ефективність.

3. Метод оцінки виконання поставлених завдань. Дозволяс отримати узагальнені висновки про роботу працівника, тому що оцінює його трудову діяльність в цілому (часто в результаті бесіди).

4. Метод «360 градусів», що включає оцінку кожного працівника керівництвом, колегами, підлеглим персоналом і самооцінку.

5. Метод групової дискусії. Передбачає відкрите обговорення результатів роботи співробітника 3 експертами, представниками HR-служби і керівництвом.

Основними перевагами якісних методів оцінки є їх простота, низький рівень трудомісткості та невисокі витрати на проведення. До основних недоліків можна віднести неточність та низький рівень надійності результатів, адже на результати впливає фактор суб’єктивної думки осіб, що проводять оцінку.

Кількісні методи оцінки персоналу засновані на оцінці таких досягнень та якостей персоналу, які можливо виміряти кількісно за допомогою спеціальних тематичних систем оцінювання 3 критеріями відповідності до певної норми, яка встановлюється компанією індивідуально. Кількісні методи оцінки персоналу включають [3]:

1. Ранговий метод. Він полягає у складанні рейтингів успішності та ефективності співробітників. Їх складають кілька менеджерів, після чого отримані дані звіряються, і персонал, який посів найбільш низькі позиції, скорочується.

2. Бальна оцінка. Передбачає нарахування балів кожному співробітнику за конкретні досягнення у трудовій діяльності. За підсумками періоду (частіше за рік) всі бали підсумовують і за ними визначають найбільш успішних та відстаючих співробітників.

3. Вільна бальна оцінка. Процес передбачає оцінку кожної якості співробітника (особистісної чи професійної) незалежними експертами. Отримані бали підсумовуються.

Основними перевагами кількісних методів є: чітка система критеріїв та факторів оцінювання, можливість врахування окремих показників та високий рівень надійності застосування. Вони вважаються найбільш об'єктивними, адже дозволяють зробити загальні висновки і вивести їх в числовому еквіваленті для подальшого зіставлення.

Комбіновані методи оцінки поєднують в собі риси якісних та кількісних методів. Їх застосування допомагає зробити проміжну оцінку роботи персоналу повнішою, що в цілому позитивно впливатиме на розвиток управління персоналу в рамках компанії. До комбінованих методів оцінки персоналу належать:

1. Метод тестування. Оцінює персонал за підсумками виконання поставлених завдань.

2. Метод підсумовування оцінок. За заданою шкалою оцінюються всі характеристики працівника, після чого середній показник порівнюється з еталонним. 
3. Метод угруповання. Передбачає об'єднання працівників в групи за результатами роботи.

Основними перевагами комбінованих методів оцінки персоналу $є$ врахування різних факторів та критеріїв оцінювання, що дає можливість порівнювати результати. До недоліків комбінованих методів оцінки персоналу відносять їх незначний рівень надійності, адже вони не завжди є об’єктивними. Процес даного виду оцінювання та отримання результатів не можна автоматизувати.

Ще однією ефективною оцінкою персоналу є комплексна. Вона полягає у реалізації методики атестації, що дозволяє охопити діяльність персоналу в цілому, у повному обсязі ії функцій. В цілому атестація виключає можливий вплив на результати суб'єктивних чинників, а отже являє собою максимально об'єктивний та достовірний метод оцінювання. Завдяки комплексному підходу виходить цілісний портрет кожного працівника, що дозволяє виявити рівень його відповідності займаній позиції в компанії. Зазвичай в організаціях атестація персоналу проводиться з періодичністю один раз на рік.

У гострій фазі кризи керівництво багатьох компаній, перейнявшись завданням оптимізацією бізнесу, звернулося до питань створення і проведення оціночних процедур. Треба визнати: частіше в основі цієї ідеї було просте бажання скоротити неефективний персонал. Проте в реальності з допомогою грамотно організованої системи оцінки можна досягти більшого.

Для початку варто перелічити деякі вигоди від проведення оцінки для підприємства:

- формування дієвих механізмів контролю ефективності менеджменту, окремих співробітників, підрозділів;

· раціональне організаційне проектування та структурно-функціональна оптимізація;

· формування інформаційної бази для опису ключових бізнес-процесів;

- створення документів і процедур для організації системи стимулювання праці на основі індивідуальних і групових КРI;

- включення показників оцінки в систему оплати праці;

- об'єктивізація оцінки реального внеску конкретного працівника в діяльність підрозділів і підприємства;

· визначення областей дефіциту персональних і групових знань співробітників і підрозділів;

- формування пулу вимог до керівників щодо ефективного управління 3 урахуванням індивідуальних особливостей співробітників;

- отримання необхідної інформації для формування ефективних навчальних і розвиваючих програм;

· підвищення професійної компетентності керівників всіх рівнів в області основних управлінських функцій.

Безумовно, щоб забезпечити отримання цих вигод, знадобиться належна підготовка, яку необхідно починати з формування та оперативної корекції цілей проведення оцінки (табл. 1). Нажаль, мета оцінки не завжди враховує особливості застосовуваних інструментів.

Таблиця 1

Цілі проведення оцінки персоналу підприємства

\begin{tabular}{|c|c|}
\hline Раціональні & Ірраціональні \\
\hline $\begin{array}{l}\text { Визначити ступінь підготовленості } \\
\text { Виявити ключових співробітників і резерв } \\
\text { Підтвердити } \\
\text { кваліфікації) }\end{array}$ & 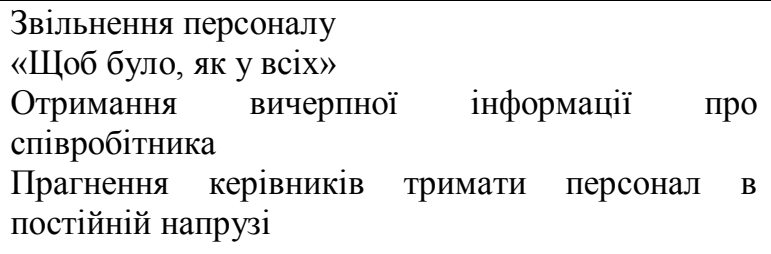 \\
\hline
\end{tabular}

Менеджменту компанії необхідно трансформувати ці установки в раціональні підходи, які приведуть, в першу чергу, не до скорочення людей, а до підвищення продуктивності їх праці.

Оцінка, як процес, орієнтована на контроль досягнення професійних цілей і КРI (при наявності), діагностику слабких місць і виявлення дефіциту професійно необхідних компетенцій співробітників, частіше передбачає подальший аналіз досягнутого і вироблення програм навчання і розвитку. Однак в іiі проведенні часто можна спостерігати серйозні помилки.

Найбільш частими з них є наступні:

· необгрунтованість проведення (за цілями і термінами);

· зайва складність процедур і методик для оцінювання;

- використання неперевіреного або вже неактуального інструментарію, головне завдання якого добитися негативного результату;

· надмірність застосовуваних методів;

- нехтування правилами;

- фокусування не на компетенціях і результатах, а на особливостях і поведінкових властивостях особистості окремих співробітників; 
· непідготовленість керівників, в першу чергу у виконанні інформаційних функцій i об'єктивному застосуванні оціночних інструментів;

· невикористання результатів проведеної оцінки в цілях розвитку співробітників.

Розглянемо ці проблеми докладніше.

Необгрунтованість проведення полягає, насамперед, в неправильній постановці цілей, ігнорування системного, регулярного та об'єктивного підходу до процесу оцінки. В цьому випадку в якості цільових орієнтирів і критеріїв виступають вже згадані питання виключно організаційно-штатної оптимізації, організаційні та особистісні конфлікти, вторинні (наприклад, загальнокорпоративні, а не професійно значущі компетенції, наявність загальнокорпоративних планів). Часто оцінюється ефективність і корисність посади, а не самого співробітника.

В якості основних можна рекомендувати наступні критерії та цільові орієнтири оцінки:

· особисті плани конкретних професійних досягнень;

· персональні KPI;

· відповідність профілю компетенції;

· спеціальні вимоги до співробітника (посади).

Важливо врахувати і можливість застосування оцінки на різних етапах діяльності співробітників при:

підборі кандидатів на вакантну позицію;

· планування професійного і кар'єрного зростання працівника;

- розробці системи навчання співробітника;

· переведення співробітника в інший структурний підрозділ;

формування кадрового резерву;

звільненні/скороченні.

Зайва складність процедур і методик для оцінюваних передбачає, що в ході проведення оцінки застосовуються громіздкі і незрозумілі співробітникам процедури, результатом яких часто стає отримання великого об'єму по-різному трактованої і часто суперечливої оціночної інформації. Нерідко серед таких організаційних методів оцінки, як асессмент-центр, експертне опитування, оцінка за результатами діяльності, тестування, пріоритет віддається останньому - у формі численних тривалих тестових завдань, контрольних i перевірочних робіт, екзаменаційних сесій, так званих IQ-тестів, головоломок і математичних вправ. Достовірність і надійність оціночних результатів у подібних випадках знижені.

Експерти оцінюють надійність методів наступним чином:

0,1-0,2 - традиційне інтерв'ю;

$0,2-0,3$ - рекомендації;

$0,3-0,45$ - професійні тести;

0,5-0,6 - структуроване інтерв'ю, інтерв'ю за компетенціями;

0,5-0,7 - когнітивні та особистісні тести;

$0,6-0,7$ - асессмент-центр.

Причому професіонали в області психологічної діагностики пропонують дуже уважно ставитися до валідності, надійності і враховувати імовірнісний і рекомендаційний характер результатів тестування.

Логічно витікає з цього, що помилкою стає використання неперевіреного або вже неактуального інструментарію, найчастіше, одержання необ'єктивного результату. Мова тут йде в першу чергу про застосування валідних, застарілих, які не пройшли процедуру адаптації тестових.

Що стосується фокусування не на компетенціях і результатах, а на особливостях і поведінкових властивостях особистості окремих співробітників, то тут мова йде про пріоритет процедури і підсумків тестування, частіше психологічного, над оцінкою результатів діяльності. Нерідко можна зіткнутися із ситуацією, коли результатом оцінки виступає виключно описовий особистісний портрет оцінюваного співробітника і саме на його основі формуються управлінські рішення стосовно співробітника і його розвиваючі програми. Виходить, що компанії орієнтують програми навчання на особистісний, а не професійний розвиток. Хоча професійні досягнення більшості співробітників залежать в першу чергу від ступеня освоєння так званих hard skills.

Фокусування уваги організаторів оцінки на підготовці до ії проведення окупається розуміючим ставленням співробітників, зниженням стресових факторів, викликаних слабкою поінформованістю, а отже, об'єктивізацією результатів.

Найважливішими елементами ефективності всього процесу оцінки $\epsilon$ роз'яснювальна інформаційна робота, широке висвітлення та роз'яснення цілей оцінки, використання результатів. Важливо в першу чергу визначити ступінь підготовленості керівників, прийняти регламент проведення оцінки, навчити керівників необхідних процедур, включаючи об'єктивне заповнення бланків експертної оцінки. 
Вірно підібрані методи оцінки та виявлення завчасно помилок допомагають виявити ключових співробітників і резерв; побудувати сфокусовані на отримання необхідних компетенцій програми навчання; максимально ефективно провести необхідні організаційні зміни; сформувати пул розвиваючих програм на постійній основі; провести оперативну корекцію методичних інструментів оцінки; правильно організувати доведення результатів оцінки до співробітників і індивідуальне консультування (на вимогу).

Отже, оцінку персоналу можна розглядати як інвестиції в тому випадку, коли в компанії існує чітке розуміння її цілей, приділяється увага всебічної підготовки, використовуються перевірені методи і процедури, а на основі результатів формуються і реалізуються актуальні програми навчання і розвитку.

Підсумовуючи можна зазначити, що вибір методу оцінювання персоналу повинен бути цілком індивідуальним. Організації часто комбінують, змінюють та підлаштовують під себе вже існуючі класичні методи, враховуючи при цьому специфіку власної діяльності. Тільки зважаючи на індивідуальні особливості компанії та маючи чітке уявлення про бажаний людський капітал можливо вибудувати якісну систему оцінювання персоналу.

\section{Список використаної літератури}

1. Головатий М. Ф. Управлінські аспекти соціальної роботи. Курс лекцій / М. Ф. Головатий , М. П. Лукашевич, Г. А. Дмитренко та ін. - К.: МАУП, 2004. - 368 с.

2. Збрицька Т. П. Управління розвитком персоналу: навчальний посібник / Т. П. Збрицька, Г. О. Савченко, М. С. Татаревська. - Одеса: Атлант, 2013. - 427 с.

3. Янцупов А.Я. Соціально-психологічна оцінка персоналу / А. Я. Анцупов, В. В. Ковальов. - 2-е вид., перероб. і допов. - М.: ЮНІТІ-ДАНА, 2012. - 391 с.

4. Мизинцева, М. Ф. Оценка персонала : учебник и практикум / М. Ф. Мизинцева, А. Р. Сардарян. Москва : Издательство Юрайт, 2014. - 378 с.

5. Міжнародний кадровий портал HeadHunter: статистичні дані з оцінки персоналу [Електронний peсурс] - Режим доступу до ресурсу: https://m.hh.ua/

6. Магура М.І. Основні принципи побудови системи відбору кадрів. // Управління персоналом. 1998г. -№11. -3. 30-35

7. Шамарін, А.В. Удосконалення процедури підбору персоналу на підприємстві Текст. / А.В. Шамарін, А.Н. Морозов, С. В. Сухоруков // Управління персоналом. - 2009. № 7.

\section{References}

1. Golovaty M. F. Managed aspects of social robot. Lecture course / M.F. Golovaty, M.P. Lukashevich, G.A. Dmitrenko and in. - K .: IAPM, 2004 . -368 p.

2. Zbritska T.P. - Odessa: Atlas, 2013 . - 427 p.

3. Yantsupov A.Ya. Social and psychological assessment of staff / A. Ya. Antsupov, V.V. Kovalov. - 2nd view., Reoff. I special stages. - M.: UNITI-DANA, 2012 . - 391 p.

4. Mizintseva, M. F. Personnel assessment: a textbook and a workshop / M. F. Mizintseva, A. R. Sardaryan. - Moscow: Yurayt Publishing House, 2014 . - 378 p.

5. International personnel portal HeadHunter: statistical data on staff assessment [Electronic resource] Access mode to the resource: https://m.hh.ua/

6. Magura M.I. The basic principle is to encourage the system to frame selection. // HR management. 1998g. -№11. -Z. 30-35

7. Shamarin, A.B. Conveniently process the staff to the staff Text. / A.B. Shamarin, A.N. Morozov, C. V. Sukhorukov // Personnel Management. - 2009. No.7. 